\title{
PENGARUH MEDIA ANIMASI TERHADAP HASIL BELAJAR DAN MOTIVASI BELAJAR SISWA MATERI SISTEM KELISTRIKAN OTOMOTIF
}

\author{
${ }^{1}$ Kadek Sukiyasa, ${ }^{2}$ Sukoco \\ ${ }^{1}$ SMKN 3 Singaraja-Bali, ${ }^{2}$ Universitas Negeri Yogyakarta \\ 1sukiyasa@gmail.com, sukocogd@yahoo.com
}

\begin{abstract}
Abstrak
Tujuan penelitian ini untuk mengetahui pengaruh penggunaan media animasi terhadap hasil belajar dan motivasi belajar materi sistem kelistrikan otomotif. Penelitian kuasi eksperimen ini menggunakan desain nonequivalent control group design. Jumlah responden sebanyak 63 orang. Instrumen pengumpulan data hasil belajar adalah tes, dan instrumen pengumpulan data motivasi belajar adalah angket. Data dianalisis dengan statistik parametris, yaitu uji-t dengan teknik independent sampel t-test dan uji lanjut dengan uji Scheffe. Hasilnya adalah terdapat pengaruh yang signifikan dari penggunaan media animasi terhadap hasil belajar dan motivasi belajar materi sistem kelistrikan otomotif pada siswa kelas X TKR di SMKN 1 Seyegan, ditunjukkan dengan hasil belajar dan motivasi belajar siswa yang diajarkan dengan media animasi lebih tinggi dari hasil belajar dan motivasi belajar siswa yang diajarkan dengan media powerpoint.
\end{abstract}

Kata Kunci: media animasi, hasil belajar, motivasi belajar

\section{EFFECT ANIMATION MEDIA ON STUDENT'S LEARNING OUTCOMES AND LEARNING MOTIVATION}

\begin{abstract}
The purpose of this study to determine the effect of animation media on learning outcomes and learning motivation the automotive electrical system material. This quasi-experimental research using nonequivalent control group design. The number of respondents being 63 students. The instrument for data collection for learning outcomes was a test, and the instrument for learning motivation was a questionnaire. The data were analyzed using parametric statistic namely t-test with independent sample t-test techniques and advanced test with Scheffe test. The result is that there is a significant effect of the use of animation media on learning outcomes and learning motivation on the automotive electrical system material among class X student of TKR of SMK Negeri 1 Seyegan, indicated by the learning outcomes and learning motivation of students who are taught by the animation media higher than the learning outcomes and learning motivation of students who are taught by powerpoint media.
\end{abstract}

Keyword: animation media, learning outcomes, learning motivation 


\section{PENDAHULUAN}

Proses belajar mengajar di kelas bertujuan untuk mencapai perubahan-perubahan tingkah laku intelektual, moral maupun sosial pada siswa. Siswa berinteraksi dengan lingkungan belajar diatur oleh guru melalui proses pembelajaran. Proses pembelajaran yang terjadi di dalam kelas ditentukan oleh beberapa komponen pembelajaran, antara lain: tujuan pembelajaran, materi/bahan ajar, metode dan media, evaluasi, peserta didik/siswa, pendidik/guru (Toto Ruhimat, dkk., 2011, p.147). Selain itu, proses belajar siswa dipengaruhi oleh lingkungan sosial keluarga, lingkungan sosial sekolah, sosial masyarakat, lingkungan alamiah, serta faktor instrumental (gedung sekolah, alat-alat belajar, fasilitas belajar, kurikulum, peraturan sekolah, buku panduan, serta silabi (Baharuddin \& Esa, 2010, pp.26-28). Dengan demikian tentu harus diupayakan suatu proses pembelajaran yang dapat menjembatani berbagai faktor-faktor terutama kelemahan-kelemahan yang ada, agar tercapai tujuan pendidikan.

Proses pembelajaran diharapkan sesuai dengan PP No.19 tentang SNP tahun 2005, yakni proses pembelajaran pada satuan pendidikan diselenggarakan secara interaktif, inspiratif, menyenangkan, menantang, memotivasi siswa untuk berpartisipasi aktif, serta memberikan ruang yang cukup bagi prakarsa, kreativitas, dan kemandirian sesuai dengan bakat, minat, dan perkembangan fisik serta psikologis siswa. Hal tersebut mengindikasikan bahwa guru sebagai pelaku proses pembelajaran di kelas, harus mampu merencanakan suatu strategi pembelajaran, agar pembelajaran yang dilaksanakan dapat berhasil dengan baik sesuai tujuan pendidikan.

Salah satu bentuk dari pendidikan adalah pendidikan kejuruan, yakni pendidikan yang spesifik, demokratis, pendidikan yang melayani berbagai kebutuhan masyarakat. Bakat, minat dan kemampuan seseorang disalurkan melalui pendidikan kejuruan. Salah satu kebutuhan yang sangat penting adalah kebutuhan akan pekerjaan agar dapat memenuhi kebutuhan hidup. Basuki Wibawa (2005, p.21) mengatakan bahwa program pendidikan teknologi dan kejuruan tidak hanya menyiapkan siswa memasuki dunia kerja, tetapi juga menempatkan lulusannya pada pekerjaan tertentu. Melalui pendidikan kejuruan, tamatan dibekali kompe- tensi tertentu sesuai bidang keahlian yang dipelajari. Wardiman (1998, p.37) mengungkapkan karakteristik Pendidikan Kejuruan tiga dari sembilan, antara lain: (1) pendidikan kejuruan diarahkan untuk mempersiapkan siswa memasuki lapangan kerja; (2) fokus isi pendidikan kejuruan ditekankan pada penguasaan pengetahuan, keterampilan, sikap dan nilai-nilai yang dibutuhkan oleh dunia kerja, serta (3) pendidikan kejuruan yang baik adalah responsif dan antisipatif terhadap kemajuan teknologi. Dengan demikian pendidikan khususnya pendidikan kejuruan penting yang berorientasi pada dunia kerja serta dapat meningkatkan pertumbuhan ekonomi. Namun kenyataanya adalah tidak mudah untuk mencapai hal tersebut di atas, karena karakteristik siswa, karakteristik sekolah yang dipengaruhi oleh pembiayaan, lingkungan dan daya dukung masyarakat menjadikan permasalahan tersendiri.

Sementara untuk dapat mengimbangi perkembangan teknologi tersebut agar kualitas pendidikan baik, dunia pendidikan juga harus dapat melengkapi segala sesuatu yang berkaitan dengan aspek tersebut. Kenyataannya adalah sarana prasarana pembelajaran yang terkait dengan teknologi tersebut tidak serta merta dapat dipenuhi oleh sekolah, sehingga merupakan sebuah masalah.

Berkaitan dengan kurikulum, kurikulum pendidikan kejuruan terbagi tiga aspek penting, yaitu aspek normatif, aspek adaptif dan aspek produktif. Pelajaran produktif terbagi dalam pelajaran teori produktif dan pelajaran praktek, dimana aspek teori produktif khususnya pada materi pelajaran sistem kelistrikan otomotif dihadapkan pada materi yang sulit divisualisasikan secara langsung. Pelajaran teori produktif kelistrikan otomotif merupakan pelajaran tentang konsep dasar yang berkaitan dengan kegiatan praktek yang akan dilakukan siswa. Siswa harus dapat memahami konsep dasar setiap standar kompetensi yang ada, agar dalam melakukan kegiatan praktek yang terkait menjadi mudah, cepat dan benar, karena untuk mendapat hasil pendidikan yang bermutu harus diawali dengan dasar yang kuat dan benar.

Standar kompetensi yang terkait dengan kelistrikan otomotif, menjadi pelajaran yang memerlukan kemampuan ekstra agar dapat menguasai dengan benar. Kelistrikan otomotif mempelajari tentang listrik yang merupakan sesuatu yang tidak tampak tetapi sesuatu itu 
ada, dapat diukur, dapat dikelola dan menghasilkan energi. Karakteristik listrik yang demikian menjadi sulit dipahami oleh siswa berkaitan dengan prinsip, konsep, serta bagaimana listrik itu berfungsi. Sifat abstrak yang demikian tentu diperlukan media untuk memudahkan dalam mempelajari atau memahaminya. Visualisasi adalah salah satu cara yang dapat dilakukan untuk mengkonkritkan sesuatu yang abstrak pada materi sistem kelistrikan kendaraan, terutama proses aliran listrik dalam penghantar.

Ditinjau dari sudut pandang pendidik, guru harus dapat mengintegrasikan kemampuannya dalam mengelola pembelajaran di kelas, salah satunya bagaimana penggunaan media untuk mempermudah penyampaian materi, serta mempermudah penerimaan materi pelajaran oleh siswa. Dengan demikian, perlu upaya untuk menjembatani permasalahan tersebut demi tercapainya keberhasilan pengajaran. Dalam hal ini penggunaan media berupa animasi yang dapat memvisualisasikan sesuatu yang abstrak.

Media yang diharapkan adalah media yang dapat memberikan penjelasan dari pelajaran abstrak menjadi bersifat kongkrit. Pelajaran yang dibuat visualisasi ke dalam bentuk gambar animasi lebih bermakna dan menarik, lebih mudah diterima, dipahami, lebih dapat memotivasi, yakni menurut Lee \& Owens (2004, p.127) bahwa penggunaan animasi dan efek khusus sangat bagus dan efektif untuk menarik perhatian peserta didik dalam situasi pembelajaran baik permulaan maupun akhir rangkaian pelajaran. Dengan kemajuan teknologi komputer tentunya memberikan kemudahan bagi guru dalam menyiapkan media pembelajaran, khususnya media animasi, namun kenyataannya masih terbatasnya penggunaan media animasi dalam proses pembelajaran, karena memerlukan keahlian khusus untuk membuat media tersebut.

Pencapaian hasil belajar dapat terlihat ketika dimunculkan dalam skor nilai, kenyataan berdasarkan observasi nilai ulangan kelas $\mathrm{X}$ TKR, bahwa masih banyak siswa yang belum mencapai batas KKM yang ditentukan. Hal ini, mengindikasikan ada permasalahan yang berpengaruh terhadap kurang maksimalnya pencapaian hasil belajar tersebut. Keadaan lain memperlihatkan bahwa kurangnya perhatian atau motivasi siswa dalam belajar di kelas merupa- kan suatu permasalahan yang saling berkaitan terutama berdampak pada hasil belajar.

Melalui penelitian ini diupayakan salah satu metode untuk mengatasi permasalahan pendidikan tersebut, khususnya metode pengajaran pada materi sistem kelistrikan otomotif. Adapun metode yang digunakan adalah penggunaan media animasi dalam penyampaian konsep kelistrikan pada standar kompetensi memperbaiki sistem starter dan pengisian, serta standar kompetensi memperbaiki sistem pengapian khususnya pada kompetensi dasar, yakni mengidentifikasi sistem dan komponennya.

Adapun rumusan masalah penelitian adalah apakah ada pengaruh media animasi terhadap hasil belajar dan motivasi belajar materi sistem kelistrikan otomotif pada siswa kelas X TKR SMK Negeri 1 Seyegan. Penelitian ini bertujuan untuk mengetahui pengaruh media animasi terhadap hasil belajar dan motivasi belajar pada siswa kelas X TKR SMK Negeri 1 Seyegan.

\section{Landasan Teori}

Proses pembelajaran dapat berjalan sesuai dengan tujuan dikarenakan banyak faktor yang berpengaruh, salah satunya adalah dipengaruhi oleh media (Toto Ruhimat, dkk., 2011, p.147). Sementara, Wang Qiyun \& Cheung Wing Sum (2003, p.217) mengatakan bahwa "...media is that they are the means or equipment that transmit information from the sender to the receiver. In the context of education, media is usually defined as instructional facilities that carry messages to learners". Dapat diartikan bahwa media merupakan sarana yang memberikan pesan kepada peserta didik atau menghubungkan informasi dari guru kepada siswa. Lebih lanjut disampaikan bahwa media dalam bentuk presentasi, meliputi: tulisan, gambar, suara, animasi dan video. Dengan demikian, penggunaan media tentu berkontribusi positif terhadap proses pembelajaran dan hasil pembelajaran khususnya hasil belajar siswa.

Terkait dengan media pembelajaran, ada beberapa jenis media yang biasa digunakan dalam proses pengajaran, yaitu; (1) media grafis meliputi; gambar, foto, grafik, bagan, poster, kartun, komik dan lain-lain; (2) media tiga dimensi dalam bentuk model meliputi; model padat, model penampang, model susun, model kerja dan lain-lain; (3) media proyeksi melipu- 
ti; slide, film strips, film, penggunaan Over Head Projector dan lain-lain, serta (4) media lingkungan (Nana Sudjana \& Ahmad Rivai, 2002, p.3). Dengan demikian metode pengajaran yang menggunakan media animasi termasuk dalam media proyeksi. Selain itu, Lee \& Owens (2004, p.117) menyebutkan ada empat kelompok media untuk pembelajaran, yaitu: (1) visual; (2) auditory; (3) olfaktory, dan (4) tactile or kinesthetic. Sementara Branch (2009, p.98) menyebutkan tiga, yakni auditory, visual dan kinesthetic. Penyampaian materi pelajaran melalui media visual peserta didik dapat menggunakan indera penglihatan, meliputi: video, grafik, animasi, dan teks tertulis (pada layar komputer, papan tulis, wallchart, transparansi, buku, poster).

Sementara adanya manfaat dari media pembelajaran, Kemp \& Dayton (1985, pp.3-4) menyebutkan manfaat daripada media pembelajaran, yaitu: (1) penyampaian pengajaran bisa lebih standar; (2) pengajaran lebih menarik; (3) proses belajar menjadi lebih interaktif; (4) waktu penyampaian materi lebih singkat; (5) kualitas pengajaran menjadi meningkat; (6) pengajaran dapat dilakukan kapan dan dimana diinginkan serta dibutuhkan; (7) sikap positif siswa terhadap apa yang dipelajari dapat ditingkatkan; serta (8) dapat mengubah peran positif guru. Selain itu juga dikatakan untuk memotivasi serta membangkitkan kemauan bertindak (Kemp \& Dayton, 1985, p.28).

Berkaitan dengan media animasi, maka Mayer dan Moreno (2002, p.88) mengemukakan bahwa animasi merupakan satu bentuk presentasi bergambar yang paling menarik, yang berupa simulasi gambar bergerak yang menggambarkan perpindahan atau pergerakan suatu objek. Penggunaan animasi dalam proses pembelajaran sangat membantu dalam meningkatkan efektifitas dan efisiensi proses pengajaran, serta hasil pembelajaran yang meningkat. Selain itu, penggunaan media pembelajaran khususnya animasi dapat meningkatkan daya tarik, serta motivasi siswa dalam mengikuti proses pembelajaran.

Sesuai dengan temuan Kadiyala and Cryners (2000); Smith and Ragan et al., (1992) dalam Balazinski \& Przybylo, (2005, p.237), yaitu pembelajaran dengan multimedia lebih efektif dan lebih efisien dari pembelajaran konvensional. Pernyataan yang sama oleh Balazinski \& Przybylo (2005) pada Journal of
Manufacturing Systems dalam penelitiannya yang berjudul Teaching Manufacturing Processes Using Computer Animation, menyebutkan bahwa penggunaan media animasi dalam pembelajaran dapat mengurangi waktu proses pembelajaran serta hasil tes meningkat sebesar 15\%. Ditambahkan pula oleh Aksoy (2012) dalam jurnal Scientific Research yang berjudul The Effects of Animation Technique on the 7th Grade Science and Technology Course menyatakan bahwa, metode animasi lebih efektif daripada metode pengajaran secara tradisional dalam menaikkan hasil belajar siswa. Sementara itu, Mayer \& Moreno (2002) pada Educational Psychology Review yang berjudul Animation as an Aid to Multimedia Learning mengemukakan bahwa animasi dapat menaikkan pemahaman siswa ketika digunakan secara konsisten sesuai teori kognitif pada pembelajaran multimedia. Pendapat tersebut memperkuat asumsi bahwa proses pembelajaran dengan menggunakan media khususnya media animasi, dimana dapat memberikan kemudahan pemahaman siswa, sehingga mampu meningkatkan pencapaian hasil belajar siswa.

Berkaitan dengan hasil belajar sebagai dampak adanya proses pembelajaran, maka terjadinya perubahan perilaku ataupun peningkatan pemahaman pengetahuan dan pengalaman merupakan sebuah hasil belajar. Klein (2002, p.2) mengatakan bahwa "learning can be defined as an experiential process resulting in a relatively permanent change in behavior that canot be explained by temporary states, maturation, on innate response tendencies". Pendapat ini sesuai dengan yang disampaikan Sugihartono, dkk. (2007, p.74) bahwa belajar merupakan suatu proses memperoleh pengetahuan dan pengalaman dalam wujud perubahan tingkah laku dan kemampuan bereaksi yang relatif permanen atau menetap karena adanya interaksi individu dengan lingkungannya. Dapat disimpulkan bahwa, hasil belajar merupakan dampak dari segala proses memperoleh pengetahuan, hasil dari latihan, hasil dari proses perubahan tingkah laku yang dapat diukur baik melalui tes perilaku, tes kemampuan kognitif, maupun tes psikomotorik.

Sementara menurut Syaiful Bahri Djamarah (2008); Sugihartono,dkk. (2007); Suharsimi Arikunto (1993); dan Baharuddin \& Esa (2010), hasil belajar siswa dipengaruhi oleh beberapa faktor yang dikelompokkan menjadi 
dua yakni bersumber dari dalam diri siswa (internal) dan dari luar siswa (eksternal). Faktor internal terdiri dari faktor jasmaniah dan faktor psikologis yang di dalamnya termasuk motivasi, sedangkan faktor eksternal terbagi atas: lingkungan sosial keluarga, lingkungan sosial sekolah, lingkungan sosial masyarakat, lingkungan alamiah, serta instrumentasi pembelajaran. Berkaitan dengan faktor instrumentasi yang ikut mempengaruhi hasil belajar peserta didik, maka dalam konteks pembelajaran, media pembelajaran turut mempengaruhi hasil belajar peserta didik. Media pembelajaran yang merupakan bagian dari proses pembelajaran yang menanamkan pengetahuan, sikap maupun keterampilan, berkontribusi terhadap hasil belajar yang akan dicapai.

Proses pembelajaran juga memerlukan adanya motivasi belajar siswa, mengingat bahwa motivasi termasuk faktor internal siswa yang berpengaruh terhadap hasil belajar. Motivasi belajar merupakan keseluruhan daya penggerak di dalam diri siswa yang menimbulkan kegiatan belajar, yang menjamin kelangsungan dari kegiatan belajar dan yang memberikan arah pada kegiatan belajar, sehingga tujuan yang dikehendaki oleh subyek belajar itu dapat tercapai. Panduan Manajemen Sekolah (1998, p.127) menyebutkan bahwa peserta didik akan termotivasi dalam belajar apabila mereka yakin yang dipelajarinya bermanfaat bagi dirinya, mampu memahami atau menguasai pelajaran tersebut, serta bila situasi belajar menyenangkan.

Berkaitan dengan menumbuhkan atau meningkatkan adanya motivasi belajar siswa, maka diperlukan suatu strategi pembelajaran yang tepat. Salah satunya adalah penggunaan media pembelajaran. Sesuai dengan pendapat Azhar Arsyad (2006, p.26) mengatakan bahwa media pembelajaran dapat meningkatkan dan mengarahkan perhatian anak sehingga dapat menimbulkan motivasi belajar, interaksi lebih langsung antara siswa dan lingkungannya, serta siswa belajar sendiri sesuai kemampuan dan minatnya. Sementara motivasi belajar materi sistem kelistrikan otomotif dapat diartikan sebagai suatu proses psikologis berupa kekuatan atau dorongan, yang dapat mengarahkan, menjaga, serta menggerakkan, yang muncul akibat rangsangan baik dari dalam maupun dari luar diri individu yang menyebabkan siswa melakukan kegiatan belajar sistem kelistrikan otomotif.
Motivasi mempunyai peranan penting dalam menentukan hal-hal yang dapat dijadikan penguat belajar, memperjelas tujuan belajar yang hendak dicapai, menentukan ragam kendali terhadap rangsangan belajar, serta menentukan ketekunan belajar (Hamzah, 2011, p.27).

Berkaitan dengan ciri-ciri adanya motivasi dalam kegiatan belajar, Sardiman (1992, p.83), menyebutkan sebagai berikut: (1) tekun menghadapi tugas; (2) ulet mengahapi kesulitan; (3) menunjukkan minat terhadap bermacammacam masalah; (4) lebih senang bekerja mandiri; (5) cepat bosan pada tugas-tugas yang rutin; (6) dapat mempertahankan pendapatnya; (7) tidak mudah melepaskan hal yang diyakini; dan (8) senang mencari dan memecahkan masalah soal-soal. Ditambahkan oleh Arden N. Frandsen dalam Sardiman (1992, p.83) menyebutkan unsur motivasi belajar, meliputi: adanya sifat ingin tahu dan ingin menyelidiki dunia yang lebih luas, adanya sifat yang kreatif pada orang yang belajar, adanya keinginan untuk selalu maju, adanya keinginan untuk memperbaiki kegagalan yang lalu.

Berbagai pendapat tersebut di atas memperkuat adanya kesimpulan bahwa, penggunaan media pembelajaran khususnya media animasi dalam proses pembelajaran sistem kelistrikan otomotif, dapat memberikan kontribusi positif terhadap peningkatan hasil belajar. Selain itu, penggunaan media pembelajaran yang memudahkan penerimaan suatu pelajaran dapat menumbuhkan maupun meningkatkan motivasi belajar siswa. Dengan demikian, dapat dibuat suatu hipotesis alternatif, yaitu; (1) hasil belajar materi sistem kelistrikan otomotif yang diajarkan dengan menggunakan media animasi lebih tinggi dari hasil belajar yang diajarkan dengan menggunakan powerpoint pada siswa kelas X TKR di SMK Negeri 1 Seyegan. (2) motivasi belajar materi sistem kelistrikan otomotif yang diajarkan dengan menggunakan media animasi lebih tinggi dari motivasi belajar yang diajarkan dengan menggunakan powerpoint pada siswa kelas X TKR di SMK Negeri 1 Seyegan.

\section{METODE}

Penelitian ini merupakan penelitian kuasi eksperimen dengan desain nonequivalent control group design (Sugiyono, 1999, p.70). Subyek penelitian siswa kelas X TKR di SMK 
Negeri 1 Seyegan, sebagai kelompok eksperimen kelas X TKR-1 dan kelompok kontrol kelas X TKR-2 berjumlah 63 siswa. Adapun kelas dipilih secara random dengan undian untuk memperoleh kelompok eksperimen dan kelompok kontrol dari ketiga kelas sebagai populasi yang memiliki homogenitas varian.

Penelitian dilakukan pada siswa kelas $\mathrm{X}$ TKR SMK Negeri 1 Seyegan mulai tanggal 1 November sampai dengan 1 Desember 2012. Teknik pengumpulan data menggunakan tes untuk variabel hasil belajar dan instrumen angket untuk variabel motivasi belajar. Validasi isi instrumen tes dan angket dengan expert judgment. Sedangkan validitas konstruk instrument tes melalui uji coba instrumen selanjutnya data dianalisis dengan program ITEMAN versi 3.0. Sementara validitas konstruk instrument angket dengan sekali tembak, selanjutnya dianalisis dengan korelasi Pearson Product Moment. Berdasarkan analisis dengan SPSS 16 for windows pada uji reliabilitas Alpha diperoleh koefisien reliabilitas sebesar 0,843 . Selain itu juga dilakukan uji validitas dengan membandingkan harga hitung pada kolom Corrected Item-Total Correlation terhadap nilai $\mathrm{r}$ tabel dengan $\mathrm{N}=63$ pada taraf signifikansi $5 \%$, maka $\mathrm{t}=0,248$. Asumsi yang digunakan adalah $\mathrm{r}$ hitung > $\mathrm{r}$ tabel, maka item valid. Berdasarkan analisis tersebut terdapat 4 item yang tidak valid yaitu item $6,9,19,22$ dan selanjutnya jumlah item yang dianalisis berjumlah 31 item. Adapun pengujian hipotesis menggunakan analisis data uji-t dengan teknik independent sample t-test (Endang Mulyatiningsih, 2011, pp.97-98) dan uji lanjut dengan uji Scheffe (Ferguson, 1985, pp.307-308). Namun sebelum dilakukan uji-t, dilakukan uji normalitas dan uji homogenitas sebagai syarat uji parametris.

Pada penelitian ini dilakukan pengontrolan internal validity, agar hasil penelitian yang dicapai memiliki validitas yang tinggi, meliputi: (1) pengontrolan terhadap Subject Characteristic dapat dilakukan karena semua subyek penelitian berjenis kelamin laki-laki, serta memiliki rentang usia yang hampir sama antar kedua kelompok yakni dari 14 tahun 7 bulan sampai dengan 17 tahun 7 bulan kelompok eksperimen dan dari 14 tahun 9 bulan sampai dengan 17 tahun 3 bulan kelompok eksperimen; (2) pengontrolan terhadap aspek Mortality, yaitu memberikan penguatan tentang pentingnya sekolah, kebermanfaatan kompeten- si keahlian yang ditekuni dengan harapan siswa merasa perlu untuk sekolah. Adapun hasilnya adalah selama kegiatan penelitian tidak ada peserta didik yang berhenti atau pindah sekolah, sehingga responden tetap; (3) pengontrolan terhadap aspek location, yaitu dapat dilakukan mengingat ruang, alat, serta pendukung yang lain yang digunakan adalah sama dari kedua kelompok (pembelajaran pada ruang kelas yang sama); (4) pengontrolan terhadap aspek instrumentation, yaitu untuk meminimalkan kesalahan dengan melakukan uji coba perangkat tes, serta telah melalui tahap validasi isi oleh expert judgment; (5) pengontrolan terhadap aspek tesing, yaitu pemberian pretes dan posttes dalam waktu yang tidak terlalu lama ataupun tidak terlalu pendek, yakni rentang waktu 28 hari; (6) pengontrolan terhadap aspek history, yaitu dipastikan tidak ada kegiatan pengayaan atau khursus tertentu di luar kegiatan pembelajaran di kelas terkait dengan materi yang diajarkan, serta proses eksperimen berlaku dalam kurun waktu tidak terlalu lama sehingga meminimalkan efek history; (7) pengontrolan terhadap aspek maturation, yaitu dengan melakukan pengukuran yang dilakukan dalam waktu relative sama yakni pagi hari sehingga tidak ada efek dari faktor kelelahan; (8) pengontrolan terhadap aspek subject attitude, yaitu dikenal juga howthorne effect adalah dengan tidak memberitahukan tentang kegiatan penelitian kepada kedua kelompok dan pembelajaran berlangsung sesuai jadwal; (9) pengontrolan terhadap aspek regression, yaitu adanya kemungkinan subyek yang mendapat nilai tinggi saat pre-tes dan mendapat nilai lebih rendah pada post-tes dan sebaliknya. Hal ini dicegah dengan jarak pengukuran antara pretes dan posttes yang tidak terlalu lama. Berdasarkan hasil penelitian diperoleh semua mengalami kenaikan skor; (10) pengontrolan terhadap aspek implementation, yaitu dengan menyiapkan rencana pelaksanaan program (RPP) serta matrik pembagian waktu dan materi, serta pelaksanaan diperhatikan sedemikian rupa supaya alur sesuai dengan yang direncanakan (Frankel \& Wallen, 1993, p.221).

Beberapa langkah pembelajaran yang dilakukan dalam penelitian ini, antara lain: (1) pada kelas perlakuan; penyampaian materi pelajaran menggunakan media animasi. Materi pelajaran khususnya pada penyampaian konsep dasar sistem kelistrikan. Mekanisme penyam- 
paian materi pelajaran sistem kelistrikan, terdiri dari; fungsi sistem, prinsip induksi dan kemagnetan, komponen sistem kelistrikan, cara kerja masing-masing sistem kelistrikan, beserta rangkaian kelistrikan (wiring diagram). Pada awal pembelajaran, siswa diberi tes untuk mengukur kemampuan awal yang disebut pretes. Setelah diberikan pretes, kelas eksperimen mendapatkan pelajaran dengan menggunakan media animasi yang disertai dengan penjelasan guru. Selama proses pembelajaran, siswa dipertahankan untuk tidak diberitahu bahwa sedang dalam penelitian, termasuk pembelajaran berlangsung sesuai jadwal yang sudah ada, dengan tujuan pengontrolan internal validity. Selama proses pembelajaran, siswa dilengkapi juga dengan buku pegangan berupa New Step sebagaimana yang sudah diharuskan oleh kompetensi keahlian. Setelah proses pembelajaran berlangsung dari beberapa pertemuan, maka siswa diberi tes akhir yang disebut postes. Adapun soal yang digunakan antara pretes dan postes adalah sama. Dalam waktu yang bersamaan siswa juga disuruh mengisi angket motivasi belajar, diawali dengan penjelasan secukupnya terkait dengan cara pengisian angket, serta cara menjawab soal; (2) pada kelas kontrol, proses pembelajaran pada kelas kontrol hampir sama dengan kelas eksperimen, yakni diawali dengan pemberian pretes pada siswa. Bentuk pretes dan postes antara kelas eksperimen dan kelas kontrol adalah sama. Adapun perbedaan pokok adalah penyampaian materi pelajaran pada kelas kontrol tidak menggunakan media animasi melainkan menggunakan media powerpoint yang dilengkapi gambar diam. Siswa juga dilengkapi dengan buku pegangan berupa New Step. Proses pembelajaran berlangsung sesuai jadwal pelajaran yang ada, selanjutnya diakhir pembelajaran, kelas kontrol juga diberikan postes, serta diminta mengisi angket diawali penjelasan cara menjawab dan cara mengisi angket. Pada kelas kontrol juga dilakukan pengontrolan internal validity dengan harapan hasil yang diperoleh merupakan akibat dari perbedaan perlakukan.

\section{HASIL PENELITIAN DAN PEMBAHASAN}

\section{Data Hasil Belajar}

\section{Data pretes kelompok eksperimen dan kontrol}

Pretes dilakukan pada awal pelaksanaan pembelajaran dengan tujuan mengetahui kemampuan awal atau mengetahui pemahaman awal, serta untuk melihat tingkat kesamaan dari kemampuan kelompok eksperimen dan kelompok kontrol. Berdasarkan hasil analisis deskriptif data diperoleh, sebagai berikut: pada kelompok eksperimen diperoleh mean $=4,3$; median $=4,3 ;$ modus $=3.5 ;$ simpangan baku $=0,987$; varian $=0,974$; skor terendah $=2,5$; skor tertinggi $=6,3$; rentangan $=3,8$ dan jumlah nilai sebesar 137,6. Sementara kelompok kontrol diperoleh mean $=4,5$; median $=4,5$; modus $=4,3$; simpangan baku $=0,708$; varian $=0,501$; skor terendah $=3,3$; skor tertinggi $=6,0$; rentangan $=$ 2,7 dan jumlah nilai sebesar 135,9. Berdasarkan deskripsi data tersebut di atas, menunjukan bahwa rerata skor hasil belajar kelompok eksperimen dan kelompok kontrol tidak berbeda jauh, yakni rerata skor kelompok eksperimen adalah 4,3, sedangkan rerata skor kelompok kontrol adalah 4,5. Berdasarkan data tersebut di atas dapat disimpulkan bahwa hasil pretes kedua kelompok tidak terdapat perbedaan yang signifikan.

\section{Data postes kelompok eksperimen}

Postes dilakukan dengan tujuan mengetahui perubahan yang terjadi pada peserta didik setelah menerima materi pelajaran dengan metode mengajar menggunakan media animasi. Perangkat tes yang dipergunakan sama dengan perangkat tes untuk pretes. Postes kelompok eksperimen dilakukan pada tanggal 29 November 2012, dimana rentang waktu antara pretes dengan postes adalah 28 hari. Adapun jumlah siswa kelompok eksperimen yang mengikuti postes adalah 32 orang siswa. Selama kegiatan proses belajar mengajar siswa kelompok eksperimen selalu hadir pada setiap pertemuan. Berdasarkan hasil analisis statistik deskriptif diperoleh nilai rata-rata (mean) $=6,5$; nilai tengah $($ median $)=6,5 ;$ nilai modus $=6,5$; varian $=0.968 ;$ standar deviasi $=0,983$; skor terendah $=4,8$; skor tertinggi $=8,3$; rentangan $=3,5$ dan jumlah nilai sebesar 208 .

\section{Data postes kelompok kontrol}

Postes dilakukan dengan tujuan mengetahui perubahan yang terjadi pada peserta didik setelah menerima materi pelajaran dengan 
metode mengajar menggunakan powerpoint. Perangkat tes yang dipergunakan sama dengan perangkat tes untuk pretes dan postes kelompok eksperimen. Postes kelompok kontrol dilakukan pada tanggal 1 Desember 2012, dimana rentang waktu antara pretes dengan postes adalah 28 hari. Semua responden mengikuti postes yakni 31 siswa. Berdasarkan hasil analisis statistik deskriptif diperoleh nilai rata-rata (mean) $=5,7 ;$ nilai tengah $($ median $)=6,0 ;$ nilai modus $=6,3 ;$ varian $=0,711 ;$ standar deviasi $=0,843$; nilai terendah $=4,3$; nilai tertinggi $=7,3$; rentangan $=3,0$ dan jumlah nilai sebesar 178 .

Berdasarkan deskripsi data tersebut di atas menunjukkan bahwa rerata skor postes kelompok eksperimen berbeda secara signifikan dengan rerata skor postes kelompok kontrol. Rerata sekor postes kelompok eksperimen adalah 6,5, sedangkan rerata skor postes kelompok kontrol adalah 5,7. Kenaikan rerata skor pretes kelompok kontrol sebesar 1,2; sedangkan kenaikan rerata skor pretes kelompok eksperimen sebesar 2,2.

\section{Data Motivasi Belajar}

Data motivasi belajar dikumpulkan menggunakan angket, dimana data terbagi dalam dua kelompok, yakni data motivasi kelompok eksperimen dan data motivasi kelompok kontrol. Bersamaan dengan postes, dilakukan pengambilan data tentang motivasi belajar dari kedua kelompok menggunakan angket skala empat. Data tersebut dimaksudkan untuk mengetahui perbedaan motivasi belajar antara pembelajaran dengan media animasi dan pembelajaran dengan media powerpoint gambar mati. Berikut ini diuraikan masing-masing data kelompok eksperimen dan kelompok kontrol.

\section{Data motivasi kelompok eksperimen}

Pengambilan data motivasi belajar dengan angket dilakukan bersamaan dengan postes. Pada saat pengambilan data semua responden hadir, yakni sebanyak 32 siswa. Gabungan kedua data digunakan untuk menghitung derajat reliabilitas dan validitas instru- men. Selanjutnya, hanya data dari item angket yang valid saja yang dianalisis yakni dari 35 item menjadi 31 item valid. Pada kelompok eksperimen yang dalam pembelajarannya menggunakan media animasi, diperoleh data motivasi dengan skor rata-rata $=99,91$; median $=100$, modus $=96$; varian $=54,41$; standar deviasi $=7,376$; skor terendah $=85$; skor tertinggi $=115$; rentangan skor sebesar 30 dan total skor 3197.

\section{Data motivasi kelompok kontrol}

Pengambilan data motivasi belajar dengan angket dilakukan bersamaan dengan postes. Pada saat pengambilan data semua responden hadir, yakni sebanyak 31 siswa. Data yang dianalisis sama dengan pada kelompok eksperimen yakni data dari item yang valid. Pada kelompok kontrol yang dalam pembelajarannya menggunakan powerpoint, diperoleh data motivasi dengan skor rata-rata $=94,35$; median $=95 ;$ modus $=95 ;$ varian $=44,903$; standar deviasi $=6,701$; total skor $=2925$; skor terendah $=78$; skor tertinggi $=106$; dan range skor sebesar 28.

Berdasarkan data motivasi belajar pada kelompok eksperimen dan kelompok kontrol dapat diketahui bahwa ada perbedaan skor ratarata motivasi antara kelompok kontrol dan kelompok eksperimen. Mean skor motivasi kelompok eksperimen sebesar 99,91 yang berarti lebih tinggi dari mean skor motivasi kelompok kontrol.

Analisis data dengan uji-t digunakan untuk membandingkan perbedaan perolehan skor postes dan skor motivasi belajar kelompok eksperimen terhadap kelompok kontrol. Pada tahap awal dilakukan analisis uji normalitas dengan menggunakan uji KolmogorovSmirnov, dengan bantuan program SPSS 16 for windows. serta dilanjutkan dengan uji homogenitas data kelompok eksperimen dan kelompok kontrol menggunakan uji Lavene. Berdasarkan uji normalitas data diperoleh data yang disajikan pada tabel 1 berikut ini. 
Tabel 1. Hasil Uji Normalitas Data

\begin{tabular}{|c|c|c|c|c|}
\hline \multirow{2}{*}{ Data } & \multicolumn{3}{|c|}{ Kolmogorov-Smirnov } & \multirow{2}{*}{ Kesimpulan } \\
\hline & Absolute & df & Sig. (p) & \\
\hline Skor Pretes Kontrol & 0,084 & 30 & 0,985 & Normal \\
\hline Skor Posttes Kontrol & 0,612 & 31 & 0,612 & Normal \\
\hline Skor Pretes Eksperimen & 0,088 & 32 & 0,965 & Normal \\
\hline Skor Posttes Eksperimen & 0,095 & 32 & 0,933 & Normal \\
\hline Skor Motivasi Kontrol & 0,162 & 31 & 0,391 & Normal \\
\hline Skor Motivasi Eksperimen & 0,091 & 32 & 0,955 & Normal \\
\hline
\end{tabular}

Berdasarkan data tabel di atas menunjukkan bahwa semua data baik data pretes, data postes, serta data motivasi dari kedua kelompok memperoleh nilai sig. ( $p$-value) >
0,05. Dengan demikian, Ho diterima yang berarti data berdistribusi normal. Selanjutnya dilakukan uji homogenitas data kedua kelompok diperoleh sebagai berikut:

Tabel 2. Hasil Uji Homogenitas Data Kedua Kelompok

\begin{tabular}{clccc}
\hline & Data & \multicolumn{2}{c}{ Lavene's tes equality of variances } & \multirow{2}{*}{ Kesimpulan } \\
\cline { 3 - 4 } & & F & Sig. & \\
\hline \multirow{2}{*}{ Equal variances assumsed } & Posttes & 0,565 & 0,064 & Homogen \\
& Motivasi & 0,883 & 0,616 & Homogen \\
& & & 0,351 & Homogen \\
\hline
\end{tabular}

Berdasarkan data hasil analisis uji lavene pada tabel di atas menunjukkan bahwa nilai sig. ( $p$-value) data pretes, data posttes serta data motivasi $>0,05$, dengan demikian kedua data homogen.
Selanjutnya dilakukan analisis uji-t. Berikut ini ditampilkan hasil uji-t variabel hasil belajar dan motivasi belajar dengan tenik independent sample tes.

Tabel 3. Hasil Uji Independent Sample T-Tes

\begin{tabular}{lccccc}
\hline variabel & T hitung & T tabel & $\begin{array}{c}\text { Df (degree of } \\
\text { freedom) }\end{array}$ & Taraf signifikansi & Kesimpulan \\
\hline Hasil Belajar & 3,279 & 2,000 & 61 & 0,05 & Signifikan \\
Motivasi Belajar & 3,124 & 2,000 & 61 & 0,05 & Signifikan \\
\hline
\end{tabular}


Melalui analisis data uji-t dengan teknik independent sample t-test, serta dengan uji Scheffe dapat diketahui adanya perbedaan dari kedua kelompok, serta kelompok mana yang memperoleh nilai lebih tinggi, berdasarkan data postes kelompok eksperimen dan kelompok kontrol. Adapun ketentuan pengujian adalah jika harga t-hitung lebih besar dari ttabel ( $\left.\mathrm{t}_{\text {hitung }}>\mathrm{t}_{\text {tabel }}\right)$ pada taraf signifikansi 5\%, maka $\mathrm{H}_{0}$ ditolak, yang berarti ada perbedaan yang ditimbulkan akibat adanya perlakuan. Adapun hasil perhitungan nilai t hitung adalah 3,279 , sementara harga $t$ tabel pada derajat bebas (degree of freedom) $\mathrm{dk}=61$ dengan taraf signifikansi 0,05 adalah 2,000. Dengan demikian, $t$ hitung $(3,279)>t$ tabel $(2,000)$, sehingga Ho ditolak yang berarti hasil belajar materi sistem kelistrikan otomotif yang diajarkan dengan menggunakan media animasi lebih tinggi dari hasil belajar yang diajarkan dengan menggunakan media powerpoint pada siswa kelas $X$ TKR di SMK Negeri 1 Seyegan. Sementara berdasarkan analisis uji Scheffe diperoleh data $\mathrm{F}_{\text {hitung }}=12,07$. Sementara, $F_{\text {tabel }}=4,00$ pada taraf signifikansi 0,05 , derajat pembilang $=1$, derajat penyebut $=61$. Hal ini berarti $F_{h}>F_{t}$, berdasarkan kriteria pengujian dengan rumus ini adalah jika $F_{h}>$ $\mathrm{F}_{\mathrm{t}}$, maka teruji bahwa $\mu_{\mathrm{i}}\left(\mu_{\text {eksperimen }}\right)>\mu_{\mathrm{j}}$ $\left(\mu_{\text {kontrol }}\right)$. Dengan demikian, dapat disimpulkan lebih lanjut bahwa terbukti hasil belajar kelompok eksperimen lebih tinggi dari hasil belajar kelompok kontrol.

Hal ini memberikan gambaran bahwa materi yang disampaikan secara lebih jelas dan lebih mendekati nyata dapat meningkatkan pemahaman peserta didik. Peserta didik lebih mudah menerima materi atau lebih mudah dipahami. Materi pelajaran yang mudah dipahami tentu memberikan hasil belajar yang lebih baik. Dengan demikian, media animasi berkontribusi positif terhadap hasil belajar, Penggunaan media animasi dalam pembelajaran materi sistem kelistrikan otomotif menunjukkan bahwa hasil belajar siswa yang diajarkan dengan media animasi lebih tinggi dari hasil belajar yang diajarkan dengan media powerpoint. Perbedaan rata-rata skor postes pada kedua kelompok menunjukkan bahwa media animasi lebih efektif dalam meningkatkan hasil belajar siswa. Dengan menggunakan media animasi dalam pembelajaran memberikan kemudahan bagi siswa dalam menerima pelajaran yang bersifat abstrak.

Sama halnya pada variabel hasil belajar, perhitungan pada variabel motivasi belajar menggunakan analisis data uji-t dengan teknik independent sample t-tes, serta dengan uji Scheffe. Adapun ketentuan pengujian adalah jika harga t-hitung lebih besar dari t-tabel $\left(\mathrm{t}_{\text {hitung }}>\mathrm{t}_{\text {tabel }}\right)$ dengan taraf signifikansi $5 \%$, maka $\mathrm{H}_{0}$ ditolak, yang berarti ada perbedaan yang ditimbulkan akibat adanya perlakuan. Adapun hasil perhitungan nilai t hitung adalah 3,124 , sementara harga t tabel pada derajat bebas (degree of freedom) $\mathrm{dk}=61$ dengan taraf signifikansi 0,05 adalah 2,000. Dengan demikian, t hitung $(3,124)>\mathrm{t}$ tabel $(2,000)$, sehingga Ho ditolak yang berarti motivasi belajar materi sistem kelistrikan otomotif yang diajarkan menggunakan media animasi lebih tinggi dari motivasi belajar yang diajarkan menggunakan media powerpoint pada siswa kelas $X$ TKR di SMK Negeri 1 Seyegan. Sementara berdasarkan analisis uji Scheffe diperoleh data $\mathrm{F}_{\text {hitung }}=9,87$. Sementara, $F_{\text {tabel }}=4,00$ pada taraf signifikansi 0,05 , derajat pembilang $=1$, derajat penyebut $=61$. Hal ini berarti $F_{h}>F_{t}$, berdasarkan kriteria pengujian dengan rumus ini adalah jika $F_{h}>$ $\mathrm{F}_{\mathrm{t}}$, maka teruji bahwa $\mu_{\mathrm{i}}\left(\mu_{\text {eksperimen }}\right)>\mu_{\mathrm{j}}$ $\left(\mu_{\text {kontrol }}\right)$. Dengan demikian, dapat disimpulkan lebih lanjut bahwa terbukti motivasi belajar kelompok eksperimen lebih tinggi dari motivasi belajar kelompok kontrol.

Berdasarkan hasil analisis di atas, menunjukkan bahwa penyampaian materi sistem kelistrikan otomotif yang menggunakan media animasi dapat meningkatkan motivasi belajar siswa. Melalui media animasi, proses kerja atau prinsip kerja suatu sistem kelistrikan dapat dicermati lebih nyata daripada media gambar diam. Peserta didik dapat mencermati materi lebih nyata terutama suatu proses kerja sistem kelistrikan, yang mana kelistrikan merupakan materi yang bersifat abstrak. Motivasi sangat diperlukan untuk meningkatkan hasil belajar. Proses belajar mengajar di sekolah tidak akan efektif jika tidak ada kesiapan pada siswa untuk belajar. Kesiapan belajar diantaranya adanya motivasi belajar pada siswa, sehingga segala pelajaran yang diberikan dapat diterima dengan baik. Penelitian menujukkan bahwa penggunaan media animasi dalam penyampaian materi sistem kelistrikan memberikan motivasi yang lebih tinggi dari- 
pada pembelajaran yang menggunakan media powerpoint. Oleh karena itu, media animasi dapat digunakan dalam menyampaikan materi yang bersifat abstrak khususnya materi sistem kelistrikan otomotif untuk menumbuhkan motivasi belajar.

\section{KESIMPULAN DAN SARAN}

\section{Kesimpulan}

Berdasarkan hasil analisis data dan pembahasan, maka hasil penelitian ini dapat disimpulkan sebagai berikut:

1. Hasil belajar siswa kelas X TKR SMK Negeri 1 Seyegan pada materi sistem kelistrikan otomotif yang diajarkan dengan media animasi lebih tinggi dari hasil belajar siswa yang diajarkan dengan media powerpoint.

2. Motivasi belajar siswa kelas X TKR SMK Negeri 1 Seyegan pada materi sistem kelistrikan otomotif yang diajarkan dengan media animasi lebih tinggi dari motivasi belajar siswa yang diajarkan dengan media powerpoint.

\section{Saran}

Berdasarkan kesimpulan di atas, maka dapat diberikan saran, sebagai berikut:

1. Guru dapat menggunakan atau membuat media animasi untuk mendukung proses pembelajaran, yaitu dalam proses penyampaian materi pelajaran yang bersifat abstrak, khususnya pada penyampaian materi sistem kelistrikan otomotif, agar proses penerimaan dan pemahaman siswa menjadi lebih mudah. Dengan demikian hasil belajar siswa lebih meningkat.

2. Guru dapat menggunakan atau membuat media animasi untuk mendukung proses pembelajaran, yaitu dalam proses penyampaian materi pelajaran yang bersifat abstrak, khususnya pada penyampaian materi sistem kelistrikan otomotif, untuk dapat menumbuhkan atau meningkatkan motivasi belajar siswa demi tercapainya tujuan pembelajaran.

\section{DAFTAR PUSTAKA}

Aksoy, G. (2012) The Effects of Animation Technique on the 7th Grade Science and Technology Course. Journal of
Scientific Research. Vol.3, No.3, 304308. Tahun 2012. Diakses dari http://www.SciRP.org/journal/ce pada tanggal 10 Agustus 2012.

Baharuddin \& Esa Nur Wahyuni. (2010). Teori Belajar dan pembelajaran. Yogya-karta: Ar -Ruzz Media.

Balazinski, M. \& Przybylo, A. (2005). Teaching manufacturing processes using computer animation, Journal of Manufacturing Sistem, 2005; 24, 3. ProQuest pg.237 Diakses dari Error! Hyperlink reference not valid. pada tang-gal 21 Juli 2012.

Basuki Wibawa. (2005). Pendidikan teknologi dan kejuruan: manajemen dan implementasinya di era otonomi. Surabaya: Kertajaya Duta Media.

Branch, R. M. (2009). Instructional design: the ADDIE approach. New York: Springer.

Depdikbud. (1998). Panduan manajemen sekolah. Jakarta: Dirjendikdasmen.

Depdiknas. (2005). Peraturan pemerintah RI nomor 19 , tahun 2005 , tentang standar nasional pendidikan.

Endang Mulyatiningsih. (2011). Riset terapan bidang pendidikan \& teknik. Yogyakarta: UNY Press.

Fraenkel, J. R. \& Wallen, N. E. (1993). How to design and evaluate research in education $\left(2^{\text {nd }} e d.\right)$. New York: McGraw-Hill Book Inc.

Ferguson, G.A. (1985). Statistical analysis in psychology and education. Singapore: McGraw-Hill International Book Company.

Hamzah B Uno. (2011). Teori motivasi dan pengukurannya: analisis dalam pendidikan. Jakarta: Bumi Aksara.

Kemp, J. E. \& Dayton, D. K. (1985) Planning \& producing instructional media $\left(5^{\text {th }}\right.$ ed.). New York: Harper \& Row, Publishers.

Klein, S. B. (2002). Learning: principles and applications $\left(4^{\text {th }} e d.\right)$. New York: McGraw-Hill Higer Education. 
Lee, W.W. \& Owens, D. L. (2004). Multimedia-based instruction design: computer-based-training, web-based training, distance broadcast training, performance-based solution. New York: Pfeiffer.

Mayer, R. E. \& Moreno, R. (2002). Animation as an aid multimedia learning. educational psychology review, Vol. 14, No.1, March 2002. Diakses dari http://search.proquest.com pada tanggal 21 Juli 2012.

Nana Sudjana \& Ahmad Rivai. (2002). Media pengajaran : penggunaan dan pembuatannya. Bandung: CV. Sinar Baru Algensindo.

Sardiman A.M. (1992). Interaksi dan motivasi belajar mengajar. Jakarta: CV. Rajawali.

Sugihartono, dkk. (2007). Psikologi pendidikan. Yogyakarta : UNY Press.
Sugiyono. (1999). Metode penelitian bisnis. Bandung: Alfabeta.

Suharsimi Arikunto. (1993). Manajemen pengajaran, secara manusiawi. Jakarta: PT.Rineka Cipta.

Syaiful Bahri Djamarah. (2008). Psikologi belajar. Jakarta: Rineka Cipta.

Wang Qiyun \& Cheung Wing Sum. (2003). Designing Hypermedia Learning Environments in Tan Seng Chee \& Wong, Angela.F.L. (Eds.). Teaching and learning with technology: an asiapasific perspective (pages: 216-231). Singapore: Prentice Hall.

Toto Ruhimat, dkk. (2011). Kurikulum dan pembelajaran. Jakarta: Rajawali Pers.

Wardiman Djojonegoro. (1998). Pengembangan sumber daya manusia: melalui Sekolah Menengah Kejuruan (SMK). Jakarta: PT. Jayakarta Agung Offset.. 